\title{
GAMBARAN KESEJAHTERAAN PSIKOLOGIS PADA REMAJA LAKI-LAKI DI SMA NEGERI SE-DKI JAKARTA
}

\author{
Susi Fitri ${ }^{1}$ \\ Meithy Intan Rukia Luawo ${ }^{2}$ \\ Ranchia Noor ${ }^{3}$
}

\begin{abstract}
Abstrak
Penelitian ini bertujuan untuk mengetahui gambaran kesejahteraan psikologis pada remaja laki-laki di SMA Negeri se-DKI Jakarta. Penelitian ini menggunakan metode deskriptif kuantitatif. Subyek penelitian ini adalah siswa laki-laki di SMA Negeri se-DKI Jakarta dengan sampel $15 \%$ dari populasi, dengan teknik multistages random sampling. Sehingga sampel yang diambil sebanyak 303 responden. Pengumpulan data dilakukan dengan menggunakan instrumen scale of psychological well-being (SPWB) yang diadaptasi dari Ryff, yang telah diuji validitas dan reliabilitasnya dan menghasilkan 60 butir pernyataan yang valid dan 24 butir pernyataan yang drop dari keseluruhan 84 butir pernyataan. Sedangkan reliabilitasnya sebesar 0,895 yang berarti tinggi. Analisa data hasil penelitian menggunakan teknik deskriptif persentase. Berdasarkan analisa data, dapat disimpulkan bahwa sebagian responden berada pada kategori sedang dengan persentase sebesar $54,45 \%$. Hal ini menunjukkan bahwa kesejahteraan psikologis pada remaja di SMA Negeri se-DKI Jakarta cukup baik. Jika dilihat per aspek, persentase tertinggi ada pada aspek penerimaan diri. Sedangkan jika dilihat per kelas tingkat kesejahteraan psikologis pada remaja laki-laki pada kelas XII memiliki persantase tertinggi.
\end{abstract}

Kata kunci: Kesejahteraan psikologis, remaja laki-laki

\begin{abstract}
This study aims to reveal the psychological well-being of the adolescent boys in Senior High Schools in DKI Jakarta. This research uses descriptive quantitative method. The subjects of this study are male students at Senior High Schools in DKI Jakarta with a sample of $15 \%$ of the populations, with multistages random sampling technique. Thus, the samples taken are 303 respondents. The data collection is done by using the instrument scale of psychological well-being (SPWB) adapted from Ryff, which has been tested for validity and reliability and produce a 60-point declaration is valid and a 24-point declaration of the overall drop 84 point statement. While the reliability of 0.895, which means high. The analysis of survey data uses descriptive techniques percentage. Based on the data analysis, it can be concluded that the majority of respondents are in the medium category with a percentage of $54.45 \%$. This indicates that the psychological wellbeing of the adolescent in SMA in DKI Jakarta is quite good. If viewed per aspect, the highest percentage is in the aspect of self-acceptance. Meanwhile, if viewed per grade level psychological well-being of the adolescent boys in class XII has the highest percentage.
\end{abstract}

Keywords: Psychological well-being, Adolescents boy

\footnotetext{
${ }^{1}$ Dosen Program Studi Bimbingan Konseling FIP UNJ, susi.fitri.kuliah@gmail.com

2 Dosen Program Studi Bimbingan Konseling FIP UNJ, meithy_intan@yahoo.com

${ }^{3}$ Mahasiswa Program Studi Bimbingan Konseling FIP UNJ, ranchia.noor.kuliah@gmail.com
} 


\section{PENDAHULUAN}

Kesejahteraan psikologis atau psychological well-being merupakan kondisi dimana seseorang memiliki fungsi mental yang baik, merasakan kebahagian, dan dapat mengoptimalkan potensi yang dimilikinya. Ryff (1995), menyatakan bahwa kesejahteraan psikologis adalah keadaan individu yang dapat menerima kekuatan dan kelemahan diri sebagaimana adanya, memilki hubungan positif dengan orang lain, mampu mengarahkan perilakunya sendiri, mampu menguasai lingkungan, serta memilki tujuan dalam hidup.

Seseorang sering merasakan bahwa dirinya tidak memiliki masalah dalam hidupnya dan merasa dalam keadaan bahagia. Pada kenyataannya, banyak kondisi-kondisi kurang menguntungkan yang menggambarkan bahwa kesejahteraan psikologis belum tercapai dengan baik terutama pada remaja. Kesejahteran psikologis pada remaja yang belum tercapai dapat dilihat dari hasil penelitian Triana Indrawati (2013) tentang kesejahteraan psikologis berdasarkan kecerdasan emosi dan dukungan sosial pada siswa SMP Terbuka, dalam penelitian tersebut mengatakan bahwa remaja sering kali terlibat dalam kenakalan seperti tawuran dan membolos pada saat jam pelajaran sekolah yang disebabkan kurangnya kesejahteraan psikologis dibidang akademik.

Salah satu indikator dari kesejahteraan psikologis menurut Hurlock (1991) adalah prestasi. Siswa yang kalah bersaing dalam mengejar prestasi akan berdampak pada kesejahteraan psikologis yang tidak optimal. Siswa tersebut akan merasa dirinya tidak mampu mengembangkan potensi yang dimilikinya. Selanjunya penerimaan diri siswa yang berprestasi akan berbeda dengan siswa yang tidak memilki prestasi sehingga menimbulkan perasaan kecewa. Ryff (1989) mengindikasikan rendahnya prestasi, penerimaan diri, pertumbuhan pribadi, dan perasaan-perasan negatif pada siswa merupakan rendahnya kesejahteraan psikologis.

Terdapat beberapa faktor yang mempengaruhi kesejahteraan psikologis, sehingga tidak semua orang memilki tingkat kesejahteraan psikologis yang sama. Penelitianpenelitian yang sudah ada menunjukkan bahwa tidak ada penentu tunggal dari kesejahteraan. Beberapa kondisi tampaknya diperlukan untuk mencapai kesejahteraan psikologis yang tinggi seperti kesehatan mental dan hubungan sosial yang positif. Faktor-faktor yang mempengaruhi pembentukan kesejahteraan psikologis diantaranya usia, gender, status sosial, ekonomi, pendidikan, budaya, religiusitas, kepribadian, dan dukungan sosial. Ryff dan Keyes (1995) menemukan bahwa aspek penguasaan lingkungan dan aspek otonomi terdapat pola yang meningkat seiiring pertambahan usia.

Hasil penelitian Cicognani (2011) menunjukkan bahwa remaja yang berusia lebih tua memiliki tingkat kesejahteraan psikologis yang lebih tinggi dibandingkan remaja yang berusia lebih muda, selain itu hasil penelitian tersebut sekaligus juga menunjukan bahwa remaja wanita memiliki tingkat kesejahteraan psikologis yang lebih tinggi dibandignkan dengan remaja pria. Tidak jauh berbeda, penelitian Carol Graham (2005) menyatakan bahwa terdapat perbedaan tingkat kesejahteraan psikologis gender dimana wanita memilki tingkat kesejahteraan psikologis yang lebih tinggi dibandingkan pria.

Terdapat beberapa perbedaan dari hasil penelitian, peneltian Cicognani menunjukkan bahwa kesejahteraan wanita lebih tinggi dari pria dan serupa dengan penelitian Carol Graham. Sedangkan penelitian Dede Hidayat Rahmat menunjukkan pelajar laki-laki memiliki kesejahteraan psikologis yang lebih tinggi dari pelajar peremuan. Oleh karena itu, penting meneliti lebih spesifik bagaimana gambaran kesejahteraan psikologis pada remaja laki-laki.

Di masyarakat, anak laki-laki dinyatakan memilki penyesuaian diri yang baik apabila ia memilki sifat mandiri, agresif, dan kuat. Standar maskulinitas di Indonesia sifatnya sangat kontekstual. Semakin banyak prasyarat yang mampu dipenuhi laki-laki maka semakin sempurna derajatnya di mata masyarakat, khususnya sesama laki-laki (Aditya, 2009). 
Dengan demikian, laki-laki akan melakukan halhal yang dapat menunjukkan maskulinitasnya. Terutama pada remaja, pada tahap ini anak laki-laki masih memiliki emosi yang labil dan akan melakukan hal yang dikatakan ideal oleh masyarakat. Namun sering terjadi kesalahan yang dilakukan remaja agar dapat dikatakan ideal oleh masyarakat. Sehingga muncul permasalahan-permasalahan pada remaja lakilaki.

Joseph Pleck (Santrock, 2007) mengatakan permasalahan-permasalahan yang muncul pada remaja laki-laki, mereka akan dianggap lebih maskulin apabila pernah melakukan hubungan seks pranikah, meminum minuman beralkohol, merokok, dan memperlihatkan perilaku-perilaku yang tidak sesuai dengan norma dan etika. Hal tersebut dapat terjadi akibat dari kurangnya pengetahuan mengenai maskulinitas yang benar dan sering terjebak dalam pergaulan yang salah agar dapat dikatakan maskulin. Santrock (2007) mengatakan bahwa remaja laki-laki cenderung enggan menceritakan masalahnya secara terbuka karena hal itu dianggap tidak maskulin.

Menurut Sarwono (2011), remaja juga identik dengan masa coba-coba. Remaja lakilaki cenderung mengikuti hal-hal yang membuat perasaannya menjadi bahagia. Dibandingkan perempuan, laki-laki cenderung lebih terlibat kompetisi, konflik, memperlihatkan egonya, mengambil resiko dan menginginkan dominasi (Santrock, 2007). Oleh karena itu, penelitian ini mengambil responden remaja laki-laki.

Berdasarkan hasil beberapa penelitian tentang kesejahteraan psikologis pada remaja laki-laki, diketahui bahwa hubungan dengan orang tua dan teman sebaya merupakan faktor utama dalam meningkatkan kesejahteraan psikologis. Santrock (1996) menjelaskan bahwa selain keberadaan orang tua, kehadiran teman sebaya dalam kehidupan remaja juga dirasa sangat penting. Selain itu, hubungan dengan teman sebaya juga turut menentukan kesejahteraan psikologis pada remaja (Townsend, McCracken, \& Witon, 1998).
Namun berdasarkan beberapa hasil penelitian ditemukan bahwa remaja laki-laki memiliki kesulitan untuk membuka diri terhadap orang lain dan sering kali menunjukkan hubungan yang bermasalah dengan teman sebaya seperti berkelahi, bermusuhan, hingga tawuran (Han \& Choi, 2005).

Penelitian yang menunjukkan bahwa rendahnya kesejahteraan psikologis pada dimensi hubungan yang positif dengan orang lain yaitu, penelitian Nita Septiani (2013) tentang gambaran psychological well-being pada remaja yang tinggal di panti asuhan. Berdasarkan hasil penelitian tersebut dimensi hubungan yang positif dengan orang lain pada remaja laki-laki memiliki skor ratarata yang paling rendah dari keenam dimensi kesejahteraan psikologis. Penelitian tersebut sejalan dengan hasil penelitian Warger dan Kleman (1986) dimana remaja laki-laki cenderung memilki masalah dalam interaksi sosial dengan teman sebaya. Hal tersebut tentu menimbulkan pertanyaan mengenai kesejahteraan psikologis pada dimensi hubungan positif dengan orang lain, karena remaja laki-laki memiliki hubungan yang bermasalah dengan teman sebaya.

\section{KAJIAN TEORI}

\section{Definisi Pengetahuan}

Kesejahteraan psikologis merupakan istilah yang menggunakan dua perspektif dalam pendefinisiannya, yaitu perspektif positive psychological functionong dan perspektif lifespan development (Ryff, 1989). Dari perspektif positive psychological functioning, yang digunakan adalah konsep Maslow mengenai aktualisasi diri, pandangan Roger mengenai individu yang berfungsi secara penuh, formulasi individuasi oleh Jung, dan konsep kematangan menurut Allport. Contohnya, dalam memperoleh kesejahteraan psikologis individu mengembangkan potensi secara penuh sehingga mendapatkan aktualisasi diri. Perspektif kedua, yaitu perspektif life-span development, menyatakan bahwa tantangan 
yang dihadapi pada tiap fase siklus hidup yang berbeda akan berbeda pula. Contoh dari perspektif ini bahwa setiap fase perkembangan pada individu memiliki kesejahteraan psikologis yang berbeda, semakin tinggi fase perkembangan yang dimiliki maka semakin tinggi kesejahteraan psikologisnya.

\section{DIMENSI-DIMENSI KESEJAHTERAAN PSIKOLOGIS}

Ryff dan Singer (2008) mengemukakan enam dimensi dari psychological well-being, yaitu:

\section{Penerimaan diri (self-acceptance)}

Penerimaan diri merupakan salah satu karakter dari individu yang mengakualisasikan dirinya sehingga mereka dapat menerima dirinya apa adanya, memberikan penilaian yang tinggi pada individualitas dan keunikan diri sendiri. Dalam mendefinisikan dimensi ini, Ryff (1989) menggunakan beberapa pemikiran dari tokoh-tokoh terdahulu seperti Rogers, Allport, Erikson, dan Maslow. Menurut Rogers (dalam Feist \& Feist, 2009), karakteristik dari kematangan. Individu ini akan memiliki keamanan emosional, mereka tidak terpuruk dengan hal yang tidak berjalan sesuai dengan harapan, mereka menyadari bahwa frustasi dan ketidaknyamanan merupakan bagian dari kehidupan. Erikson (dalam Ryff, 1989) berpendapat bahwa hal ini juga melibatkan penerimaan akan masa lalu, dengan keberhasilan dan kegagalan yang dialami individu. Begitu pula dengan Maslow, ia berpendapat bahwa penerimaan diri merupakan salah satu syarat aktualisasi diri.

Dari penjabaran tersebut, menurut Ryff (1995) kriteria seseorang yang memiliki skor dimensi penerimaan diri yang tinggi dideskripsikan sebagai individu yang memilki sikap positif terhadap diri sendiri, mengetahui dan menerima berbagai aspek diri (baik kualitas baik maupun kualitas buruk) merasa positif akan kehidupan masa lalu.

2. Hubungan positif dengan orang lain (positive relations with others)

Dimensi penting lain dari psychologicalwell-being adalahkemampuan individu untuk membina hubungan yang hangat dengan orang lain. Allport (dalam Ryff, 1989) memasukkan hubungan yang hangat dengan orang lain sebagai kriteria dari kematangan, yaitu kemampuan untuk memiliki keintiman yang luas dalam cinta, baik dengan anggota keluarga atau teman, dan menunjukkan kasih sayang, penghormatan, dan harapan yang dimiliki orang lain, serta tidak mengeksploitasi orang lain untuk keuntungan pribadinya. Erikson juga memasukkan kemampuan menjalin hubungan yang intim dengan orang lain (intimacy) sebagai salah satu tugas perkembangan, terutama pada tahap dewasa muda. Kemampuan untuk menjalin hubungan yang positif dengan orang lain ini ditekankan berulang kali dalam teori positive functioning, maka Ryff menetapkan hal ini sebagai salah satu dimensi psychological well-being.

\section{Otonomi (autonomy)}

Dimensi otonomi menyangkut kemampuan untuk menentukan nasib sendiri (self-determination), bebas dan memilki kemampuan untuk mengatur perilaku sendiri. Menurut Maslow (dalam Feist \& Feist, 2009), otonomi merupakan salah satu syarat aktualisasi diri, dengan demikian inidividu bergantung pada diri sendiri untuk perkembangan dirinya. Otonomi tidak berarti antisosial atau tidak konform, melainkan mengikuti standar tingkah laku pribadi dan tidak begitu saja mengikuti aturan diri orang lain.

$$
\text { Rogers (Ryff, 1989) pun }
$$
berpendapat bahwa individu yang berfungsi secara penuh akan memiliki lokus evaluasi internal. Dengan demikian, individu akan mengevaluasi dirinya berdasarkan standar 
pribadi, bukan standar yang dianut orangorang lain. Selain Maslow dan Rogers, pentingnya regulasi tingkah laku dari dalam diri juga ditekankan oleh Jahoda (Ryff, 1989). Berbeda dengan tokoh-tokoh sebelumnya, Jung lebih menekankan konsep otonomi pada pembebasan diri dari konvensi/adat, yang berarti individu tidak lagi terikat dengan ketakutan bersama, kepercayaan, dan hukum yang dianut orang banyak.

Dari penjelasan tersebut Ryff (1995) memformulasikan karakteristik individu yang memilki otonomi adalah memiliki kepastian diri dan mandiri, dapat bertahan dari tekanan sosial untuk berpikir dan bertingkah laku dengan cara tertentu, meregulasi tingkah laku dari dalam diri sendiri, serta mengevaluasi diri sendiri, serta mengevaluasi diri berdasarkan standar pribadi.

4. Penguasaan lingkungan (enviromental mastery)

Penguasaan lingkungan merupakan kemampuan individu untuk memilih, menciptakan dan mengelola lingkungan agar sesuai dengan kondisi psikologisnya dalam rangka mengembangkan diri. Menurut Allport (dalam Ryff, 1989) mendeskripsikan individu yang matang sebagai seseorang yang membangun ketertarikan yang kuat di luar diri dan berpartisipasi dalam aktivitas manusia. Individu ini memiliki persepsi yang realistis terhadap lingkungan di sekitarnya, mereka tidak hidup di dunia khayalan dan tidak membelokkan realita untuk menyesuaikannya dengan harapan mereka (dalam Feist \& Feist, 2009).

Dalam pembahasan penguasaan lingkungan, Buhler (Ryff, 1989) juga menyatakan bahwa manusia memilki kecenderungan untuk mengubah dunia disekelilingnya melalui aktivitas fisik ataupun mental. Birren dan Renner juga mengemukakan bahwa seseorang yang sehat secara mental akan mengambil kesempatan- kesempatan yang muncul di lingkungan sekitarnya. Kesimpulannya, perspektif ini menyatakan bahwa partisipasi aktif dan penguasaan lingkungan merupakan hal yang penting bagi seorang individu untuk dapat berfungsi secara maksimal.

Berdasarkan penjabaran tersebut, kriteria yang ditetapkan untuk dimensi penguasaan lingkungan adalah memiliki rasa penguasaan lingkungan dan kompetensi dalam mengatur lingkungan, mengontrol kelompok aktivitas eksternal yang kompleks, menggunakan kesempatan di sekitar dengan efektif, dapat memilih atau menciptakan konteks yang sesuai dengan kebutuhan dan nilai pribadi (Ryff, 1995).

5. Tujuan dalam hidup (purpose in life)

Adanya tujuan hidup yang jelas merupakan bagian penting dari karakteristik individu yang memilki kesejateraan psikologis. Teori-teori perkembangan lifespan menjelaskan proses perkembangan sesuai dengan tujuan seseorang dalam kehidupannya. Terdapat berbagai teori dari beberapa tokoh mengenai tujuan individu dalam kehidupan. Buhler menyatakan tujuan individu pada usia madya adalah mengubah dunia dengan kreatif. Erikson berpendapat pencarian integrasi emosional merupakan tujuan individu. Di sisi lain, Rogers berpendapat bahwa tujuan individu yang berfungsi secara penuh adalah peningkatan kehidupan eksistensial, yaitu menghayati kehidupan pada setiap memennya. Individu yang berfungsi secara penuh memilki tujuan yang positif, kuat, sense of directedness, yang seluruhnya berkontribusi pada sense of meaningfulness dan integrasi mengenai berbagai bagian pada kehidupannya.

Dari penjabaran tersebut, individu yang memilki tujuan hidup menurut Ryff (1995) akan memiliki tujuan dalam hidup dan rasa kebertujuan, merasa bahwa terdapat makna dari kehidupan saat ini dan masa lalu, berpegang pada kepercayaan yang memberikan tujuan hidup memilki 
keinginan dan tujuan untuk kehidupan.

6. Perkembangan pribadi (personal growth)

Dimensi ini berkaitan dengan cara individu memandang dirinya dan harkat manusia untuk selalu tumbuh dan berkembang. Syarat perkembangan yang optimal tidak hanya pencapaian dimensi-dimensi yang telah dijabarkan sebelumnya, tetapi juga pengembangan berkelanjutan dari potensi seseorang, untuk terus bertumbuh dan berkembang sebagai seorang manusia (Ryff, 1989). Ryff juga berpendapat bahwa keadaan dunia yang selalu berubah membutuhkan perkembangan diri yang berkelanjutan pula. Keinginan untuk menjadi sebuah proses ini juga dinyatakan oleh Rogers sebagai karakteristik penting untuk dapat berfungsi secara penuh. Seseorang yang berfungsi secara penuh akan berkembang secara berkelanjutan, dan menjalani proses, bukan mencapai keadaan konstan dimana seluruh masalah telah terselesaikan. Begitu pula menurut Maslow, usaha untuk aktualisasi diri yang mewujudkan ideal perkembangan tertinggi bagi individu merupakan sebuah proses yang berkelanjutan.

Buhler juga mengemukakan mengenai perkembangan berkelanjutan individu, yaitu proses adaptasi individu atas keterbatasan dirinya menjadi perkembangan kreatif untuk meningkatkan ketentraman dalam diri. Oleh karena itu, kualitas perkembangan diri yang berkelanjutan dinyatakan sebagai dimensi kesejahteraan psikologis dalam model yang terintegrasi.

Dari penjelasan sebelumnya, menurut Ryff (1995) individu yang optimal pada dimensi perkembangan diri ini didefinisikan dengan kriteria berupa memilki perkembangan yang berkelanjutan, melihat diri sebagai individu yang bertumbuh dan berkembang, memiliki rasa akan menyadari potensi dirinya, melihat perkembangan dalam diri dan perilaku sepanjang waktu; serta berubah alam cara- cara yang merefleksikan pengetahuan diri dengan kefektifan yang lebih baik.

\section{Remaja Laki-laki}

Remaja di definisikan sebagai suatu periode perkembangan dari transisi antara masa anak-anak dan dewasa, yang diikuti oleh perubahan biologis, kognitif, dan sosioemosional Santrock (2007). Sedangkan menurut Piaget (dalam Hurlock, 1999), mengatakan bahwa secara psikologis masa remaja adalah usia dimana anak tidak merasa di bawah tingkat orang-orang yang lebih tua, melainkan berada di dalam tingkatan yang sama, sekurang-kurangnya dalam masalah hak.

Dalam perkembangan individu, orang tua memberikan model yang pertama dalam perilaku gender. Namun tidak lama kemudian, kawan sebaya juga berespons dan memberikan model perilaku maskulin dan feminin. Di mana anak-anak laki saling mengajarkan perilakuperilaku maskulin terhadap satu sama lain dan kemudian memperkuatnya.

Menurut Maccoby (2002) remaja laki-laki cenderung lebih banyak berinteraksi dengan kelompok yang lebih besar yang memilki struktur hierarkis, dan kelompok mereka biasanya memilki seorang pemimpin yang mengatakan apa yang harus dilakukan dan bagaimana caranya. Remaja laki-laki cenderung lebih berpartisipasi dalam permainan dan olahraga yang terorganisasi. laki-laki cenderung lebih terlibat dalam kompetisi, konflik, memperlihatkan egonya, mengambil risiko, dan menginginkan dominasi. Permainan lakilaki memiliki pemenang dan orang yang kalah sering kali menjadi subjek argumentasi. Lakilaki sering kali meningkatkan keterampilan mereka dan berpendapat mengenai siapa yang terbaik dan dalam hal apa.

Pollack (1999) berpendapat bahwa remaja laki-laki sangat sedikit memperlihatkan emosi seiring dengan pertumbuhannya. Remaja laki-laki terlalu sering kali dididik untuk tidak memperlihatkan perasaaan-perasaaan dan bertindak tangguh. Remaja laki-laki cenderung 
enggan menceritakan masalahnya secara terbuka karena hal itu dianggap tidak maskulin. Remaja laki-laki akan membuat dirinya dijuluki "pengecut" apabila mereka tidak mampu menangani masalah serta perasaan tidak aman yang dirasakannya. Pollack maupun banyak orang berpendapat bahwa laki-laki dapat memperoleh keuntungan apabila mereka diajarkan untuk mengekspresikan kecemasankecemasan dan kekuatiran-kekuatiran yang dirasakan maupun untuk meregulasikan agresinya, dibandingkan apabila mereka memendamnya.

Remaja laki-laki telah belajar mengenai aturan laki-laki di berbagai konteks, lapangan bermain, ruang kelas, perkampungan, tempat berkumpul. Lingkungan sekolah mempunyai peranan dalam perkembangan individu, terdapat kekuatiran bahwa kawan sebaya remaja laki-laki mempengaruhi perilaku yang nakal di sekolah (Koch, 2003). Perilaku nakal yang terjadi oleh remaja laki-laki di sekolah adalah : Remaja laki-laki kurang mematuhi aturan dan tidak disiplin, banyak memilki masalah dalam belajar, banyak memperoleh kritik, dan kurangnya prestasi dalam bidang akademis yang berakibat pada ranking rendah dan tinggal kelas.

Permasalahan kekerasan pada remaja laki-laki sering terlibat dalam perilaku antisosial dibandingkan remaja perempuan, meskipun anak perempuan lebih sering melarikan diri dari rumah, remaja laki-laki lebih sering terlibat dalam perilaku kekerasan. Menurut Santrock (2007) Remaja laki-laki yang nakal sering kali berasal dari keluarga di mana orang tua jarang mengawasi anaknya, kurang memberikan dukungan, dan menerapkan disiplin yang tidak efektif. Faktor status sosio-ekonomi yang rendah dapat mengakibatkan perilaku remaja laki-laki menjadi nakal Memiliki kawan-kawan yang nakal dapat meningkatkan individu menjadi nakal.

Masa remaja merupakan masa pubertas. Pubertas yang dialami oleh anak lakilaki ditandai dengan telah mengalami mimpi basah, tumbuhnya jakun, tumbuhnya bulu- bulu halus, dan sebagainya. Menurut Santrock (2007) pubertas memperkuat aspek-aspek seksual dari sikap dan perilaku maskulin remaja laki-laki. Mereka akan menampilkan perilaku yang asertif, sombong, dan kuat, karena mereka beranggapan bahwa perilaku semacam itu dapat meningkatkan seksualitasnya. Para remaja laki-laki saling bersaing dalam menampilkan perilaku maskulin untuk menjalin hubungan dengan remaja perempuan. Namun, terdapat kekuatiran khusus mengenai remaja lakilaki yang mengadopsi peran maskulin secara kuat, karena hal ini berkaitan dengan perilaku bermasalah.

\section{METODOLOGI PENELITIAN}

Penelitian ini dilakukan di SMA Negeri di seluruh DKI Jakarta. Penelitian ini di laksanakan pada bulan maret sampai bulan desember 2016. Peneliti menggunakan metode penelitian deskriptif dalam penelitian survey. Penelitian deskriptif adalah penelitian yang bertujuan untuk mengumpulkan informasi mengenai suatu gejala yang ada (Arikunto, 2006)

Pada penelitian ini, yang menjadi populasi penelitian adalah remaja SMA Negeri di lima wilayah DKI Jakarta, yaitu 36.529 siswa dari 134 SMA Negeri di DKI Jakarta. Pada penelitian ini, teknik sampel yang digunakan adalah Gugus Bertahap Ganda (dua atau lebih) atau Multistages Sampling. Sehingga, dengan teknik pengambilan sampling yang digunakan terdapat total sampel responden sekitar 303 siswa yang akan mewakili DKI Jakarta.

Instrumen kesejahteraan psikologis menggunakan adaptasi dari Scale of Psychological Well-Being (SPWB) yang disusun oleh Ryff (1989). Pengukuran kesejahteraan psikologis ini menggunakan Skala Likert yang terdiri dari 4 pilihan jawaban.

\section{HASIL DAN PEMBAHASAN}

Penelitian yang telah dilakukan kepada 303 siswa laki-laki SMA Negeri yang berada di wilayah DKI Jakarta sebagian besar berada pada kategori sedang, artinya sebagian 
besar remaja laki-laki memilki kesejahteraan psikologis yang cukup baik. Selanjutnya kategorisasi tinggi kesejahteraan psikologis pada remaja laki-laki berada diurutan kedua setelah kategori sedang dan di atas kategori rendah. Apabila diurutkan, maka kategorisasi kesejahteraan psikologis pada remaja laki-laki di SMA Negeri se-DKI Jakarta yaitu kategori sedang, tinggi, dan kategori rendah.

Aspek-aspek yang terdapat dalam kesejahteraan psikologis menurut Ryff (2008) terbagi menjadi enam dimensi, pada penelitian ini persentase kesejahteraan psikologis per aspek mayoritas berada pada kategorisasi sedang. Remaja laki-laki telah memiliki kesejahteraan psikologis per aspek dengan cukup baik, dimana aspek penerimaan diri, otonomi, penguasaan lingkungan, dan aspek tujuan dalam hidup pada remaja laki-laki berada di kategorisasi sedang dengan jumlah persentase yang lebih tinggi dibandingkan aspek hubungan yang positif dengan orang lain dan aspek perkembangan pribadi. Hal ini sesuai dengan dari hasil penelitian yang dilakukan oleh Ryff (1995) tentang kesejahteraan psikologis pria dan wanita, dimana skor aspek hubungan positif dengan orang lain dan aspek perkembangan pribadi pada pria lebih rendah.

Aspek hubungan positif dengan orang lain yang lebih rendah dari aspek lainnya sesuai dengan penelitian yang dilakukan Nita Septiani (2013)yang mengatakan bahwa aspek hubungan yang positif dengan orang lain memilki skor rata-rata yang paling rendah. Hal tersebut disebabkan karena remaja laki-laki memilki kesulitan untuk membuka diri terhadap orang lain dan sering kali menunjukkan hubungan yang bermasalah dengan teman sebaya seperti berkelahi, bermusuhan, dan tawuran (Han \& Choi, 2005). Rendahnya persentase pada aspek hubungan yang positif dengan orang lain dapat dilihat dari remaja laki-laki memiliki kesulitan untuk memilki hubungan yang hangat, memuaskan, dan saling mempercayai orang lain serta peduli dengan kesejahteraan orang lain.

Aspek penerimaan diri yang memiliki posisi teratas pada kategorisasi sedang menunjukkan bahwa remaja laki-laki telah memilki sikap yang positif terhadap diri sendiri dan memiliki perasaan yang positif terhadap masa lalu yang cukup baik. Hal ini sejalan dengan penelitian Muhammad Ridha (2012) yang menunjukkan bahwa penerimaan diri remaja laki-laki lebih tinggi dari pada perempuan. Penerimaan diri yang tinggi pada remaja laki-laki dipengaruhi oleh citra tubuh remaja laki-laki yang digambarkan maskulin memilki penerimaan diri yang lebih tinggi. Remaja laki-laki dapat menerima keadaan dirinya pada saat ini dan menanggapi masa lalunya dengan hal yang positif.

Posisi kedua pada kategorisasi sedang yaitu aspek otonomi, aspek ini menunjukkan kemampuan laki-laki yang telah mampu mandiri serta dapat mengatasi tekanan sosial. Tingginya persentase aspek otonomi remaja laki-lakipada kategori sedang disebabkan oleh adanya perbedaan sifat kemandirian pada lakilaki dan perempuan (Hurlock, 1999). Anak laki-laki diberi lebih banyak kesempatan untuk berdiri sendiri dan menanggung resiko dan banyak dituntut untuk menunjukkan inisiatif dan maskulinitas. Menurut teori belajar Kolhberg (Monks, 2002) perbedaan tingkah laku dari jenis kelamin timbul karena pengaruh lingkungan sosial, anak laki-laki lebih memiliki kebebasan untuk bertingkah laku dibandingkan dengan anak perempuan. hal tersebut dapat dilihat dari aspek penguasaan lingkungan yang berada pada urutan ketiga dalam kategorisasi sedang.

Aspek penguasaan lingkungan pada remaja laki laki disebabkan oleh kematangan sebagai seseorang yang membangun ketertarikan yang kuat di luar dan berpartisipasi dalam aktivitas manusia (Ryff, 1989). Disini terlihat bahwa remaja laki-laki telah mampu mengefektifkan penggunaan peluang yang ada disekitar serta mampu untuk mengatur lingkungannya.

Posisi keempat pada kategorisasi sedang yaitu aspek tujuan hidup, remaja laki-laki memiliki tujuan dan sasaran yang 
ingin dicapai dalam hidup dengan cukup baik. Penelitian Lina Ria Erfiana (2012) menyatakan bahwa mayoritas remaja laki-laki memiilki kemandirian pada kategori sedang dan memilki tujuan dalam hidup pada kategori sedang. Sehingga terdapat hubungan positif antara tujuan dalam hidup dengan kemandirian atau semakin tinggi tujuan dalam hidup maka semakin tinggi kemandirian pada remaja lakilaki.

\begin{abstract}
Sedangkan posisi kelima pada kategorisasi sedang adalah aspek perkembangan pribadi. Menurut Ryff (1995) remaja laki-laki menganggap diri mereka dapat membuat kemajuan yang signifikan dan mengembangkan diri mereka untuk masa depan. Dapat dilihat dari kemampuan remaja laki-laki untuk selalu berubah dalam konteks pengembangan sikap atau perilaku baru.
\end{abstract}

Penelitian Ryff (1989) untuk melihat perbandingan kondisi kesejahteraan psikologis pada remaja, dewasa, dan orang tua menunjukkan bahwa kesejahteraan psikologis pada dewasa lebih tinggi dibanding remaja. Penelitian tersebut menunjukkan semakin bertambah usia seseorang maka akan lebih tinggi tingkat kesejahteraan psikolgisnya. Hasil penelitian gambaran kesejahteraan psikologis pada remaja laki-laki di SMA Negeri se-DKI Jakarta per kelas menunjukkan kelas XII atau kelas yang paling tinggi di SMA memilki tingkat kesejahteraan psikologis yang lebih tinggi dibandingkan dengan kelas XI dan kelas X. Terlihat bahwa kelas yang lebih tinggi memilki kesejahteraan psikologis yang lebh tinggi, dapat digambarkan bahwa usia remaja laki-laki yang lebih tinggi akan berdampak pada kesejahteraan psikologis yang lebih tinggi.

Tabel 1. Data Keseluruahan Gambaran Kesejahteraan Psikologis pada Remaja Laki-Laki di SMAN se-DKI Jakarta

\begin{tabular}{cccc}
\hline Kategorisasi & Rentang & $\begin{array}{c}\text { Jumlah } \\
\text { Siswa }\end{array}$ & Persentase \\
\hline Tinggi & Di atas 248 & 91 & $30.03 \%$ \\
Sedang & 217 sampai 248 & 165 & $54.45 \%$ \\
Rendah & 186 sampai 217 & 47 & $15.51 \%$ \\
JUMLAH & & 303 & $100 \%$ \\
\hline
\end{tabular}

\section{SARAN}

1. BagiSiswa/RemajaLaki-laki.Berdasarkan hasil penelitian ini diharapkan para siswa dapat menggunakan bantuan layanan BK disekolah dengan melakukan bimbingan maupun konseling bersama Guru BK agar dapat meningkatkan kesejahteraan psikologis yang lebih baik terutama dalam aspek hubungan yang positif dengan orang lain dan aspek perkembangan pribadi.

2. Bagi Guru Bimbingan dan Konseling. Hasil penelitian ini diharapkan dapat menjadi bahan pertimbangan bagi guru BK dalam memberikan layanan preventif dan responsif untuk meningkatkan kesejahteraan psikologis pada remaja lakilaki. Salah satunya adalah memberikan motivasi dan pengetahuan mengenai kesejahteraan psikologis, baik melalui layanan klasikal maupun layanan individual.

3. Bagi Mahasiswa / Peneliti Selanjutnya. Hasil penelitian ini dapat digunakan sebagai bahan rujukan untuk penelitian selanjutnya mengenai kesejahteraan psikologis pada remaja, dengan melihat faktor-faktor kesejahteraan psikologis yang belum dibahas didalam penelitian ini. Seperti faktor perbedaan status sosial, dukungan sosial, pekerjaan, kesehatan fisik, dan faktor kepribadian.

\section{DAFTAR PUSTAKA}


Graham, C. (2005). Gender and Well-being around the World. Jurnal of Global and Development.

Cicognani, E. (2011). Coping Strategies with Minor Stressors in Adolescence: Relationship with Social Support, Self-Efficacy, and Pychological Wellbeing. Journal of Applied Social Psychology, 41 (3), 559-578.

Erfiana, L.R. (2012). Hubungan antara Kebermaknaan Hidup dengan Kemandirian pada Remaja. Jurnal Psikologi Universitas Ahmad Dahlan.

Feist, J. \& Feist, G. J (2009). Theories of personality. Singapore: McGrawHill.

Hidayat, D.R. \& Herdi. (2013). Bimbingan Konseling Kesehatan Mental di Sekolah. Bandung: PT Remaja Rosdakarya.

Hurlock. (1999). Psikologi Perkembangan. Jakarta : Erlangga.

Indrawati, Triana. (2013). Peranan Kecerdasan Emosi dan Dukungan Sosial terhadap Kesejahteraan Psikologis pada Siswa SMP Terbuka. (Unpublished master's thesis). Universitas Gadjah Mada, Yogyakarta.

Maccoby, E.E. (2002). Contemporary Research On Parenting: The Case For Nature And Nurture. Jurnal American Psychologist.

Ridha, Muhammad. (2012). Hubungan antara Body Image dengan Penerimaan Diri pada Mahasiswa. Jurnal Psikologi Universitas Ahmad Dahlan.
Ryan, R. M. \& Deci, E. L. (2001). On happiness and human potentials: a reviewof research on hedonic and eudaimonic well-being. Empthaty, 3 1(1), 111-121.

Ryff, C. D. (1989). Happiness is everything, or is it? Explorations on the meaning of psychological well-being. Journal of Personality and Social Psychology.

Ryff, C. D. (1995). Psychological wellbeing in adult life. Jurnal Current Directionsin Psychological Science.

Ryff, C. D. (2008). Know thyself and become what you are: a eudaimonic approach to psychological wellbeing. Journal of Happiness Studies.

Santrock, John W. (1996). Adolescence (2th ed.). Boston : McGraw Hill.

Santrock, John W. (2007). Remaja. Jakarta: Erlangga.

Septiani, Nita. (2013). Gambaran Psychological Well-being pada remaja yang tinggal di Panti Asuhan. (Unpublished undergraduate thesis). Universitas Indonesia, Depok.

Warger, C., \& Kleman, D. (1986). Devoloping Positive Self-Concepts in Institutionalized Children with Severe Behavior Disorders. Journal of Child Welfare, 2. 165-177. 